\title{
Enlightened Mills
}

\author{
Mechanizing Olive Oil Production in \\ Mediterranean Europe
}

\section{MASSIMO MAZZOTTI}

During the second half of the eighteenth century, government administrators and entrepreneurs in different parts of Mediterranean Europe employed a mix of Enlightenment ideas and advanced technology to revitalize the economies of their countries. These reformers denounced the secular stagnation of the Mediterranean world, a stagnation they described as both an economic and a cultural-or, as they put it, moral-phenomenon. Political and social advancement, they thought, would follow naturally from economic liberalization and the introduction of new technologies. In the end, of course, the modernization of Mediterranean Europe proved a slow and difficult process. The diffusion of modern machinery through the landscape, technology transfer from one region to another-these were not straightforward tasks.

Reformers focused in particular on olive oil production, by far the most important commercial activity in the region. ${ }^{1}$ In the second half of the eighteenth century a sizable international market for olive oil developed, and certain enlightened reformer-entrepreneurs advocated rationalizing

Dr. Mazzotti is lecturer in sociology at the University of Exeter. He is currently researching the cultural and social history of the manufacture of olive oil and silk in early modern Europe. He thanks Robert Friedel, Pamela Long, the participants in the postdoctoral reading group at the Dibner Institute, and the Technology and Culture referees for their comments on earlier versions of this article.

(C)2004 by the Society for the History of Technology. All rights reserved. 0040-165X/04/4502-0002\$8.00

1. The single most important export of the kingdoms of Portugal and Naples, olive oil was also crucial to the economies of the French and Italian Rivieras. Silk throwing was also important in these regions, although much less widespread. On the mechanization of silk throwing, see Walter English, "A Study of the Driving Mechanisms in the Early Circular Throwing Machine," Textile History 1 (1971): 65-75, and Carlo Poni, "The Circular Silk Mill: A Factory before the Industrial Revolution in Early Modern Europe," History of Technology 21 (1999): 65-85. On other aspects of silk technology, see Simonetta Cavaciocchi, ed., La seta in Europa (Florence, 1993). 
and mechanizing oil production as a way of meeting this increased demand. The economic importance of olive oil in European markets extended well beyond its uses in the kitchen; it was also the best industrial lubricant available and the most efficient fuel for lighting. The business of olive oil was thus closely tied to the growth of industrial machinery in northern Europe, and southern reformers saw in it their best hope of catch-

APRIL

2004

VOL. 45 ing up with the rest of the continent. A sociohistorical understanding of eighteenth-century oil manufacture is therefore crucial to assessing southern European industrialization and its relation to the economies of northern Europe.

The early processes of mechanization in oil manufacture were highly local and contingent in nature, far from incarnating some necessary stage in the establishment of a modern factory system. ${ }^{2}$ The traditional design of olive oil machinery (fig. 1) was a constitutive element of southern European societies. Modifying it meant modifying traditional landscapes and ways of life as well. Reformers focused not only on machines, then, but also on the sociocultural meanings associated with them; they sought to influence the intersection of Enlightenment culture, labor organization, and technical design. And indeed, technical innovation succeeded only where reformers succeeded in reshaping traditional ways of life as well as traditional machinery. ${ }^{3}$

The history of olive oil manufacturing technology lends support to a relativistic view of technical artifacts - that is, to the idea that notions like "effecting improvements," "working better," or even simply that a machine can be said to "work" or "not work" are relative to specific conditions and expectations, not deducible from intrinsic features of the machine itself. ${ }^{4}$

2. For similar considerations on preindustrial textile manufacture, see Charles Sabel and Jonathan Zeitlin, "Historical Alternatives to Mass Production: Politics, Markets and Technology in Nineteenth-Century Industrialization," Past and Present 108 (1986): 133-76.

3. Thomas Hughes's conception of sociotechnical systems and the image of a network elaborated by Bruno Latour, Michel Callon, and John Law could certainly be used to frame important aspects of the history of olive oil production; indeed, they have been a powerful source of inspiration for this article. However, the argument presented here does not rely on the theoretical assumptions usually associated with these ideas. See Thomas P. Hughes, Networks of Power: Electrification in Western Society, 1880-1930 (Baltimore, 1983); Michel Callon, "Society in the Making: The Study of Technology as a Tool for Sociological Analysis," in The Social Construction of Technological Systems: New Directions in the Sociology and History of Technology, ed. Wiebe E. Bijker, Thomas P. Hughes, and Trevor J. Pinch (Cambridge, Mass., 1987), 83-103; and Bruno Latour, Science in Action: How to Follow Scientists and Engineers through Society (Cambridge, Mass., 1987).

4. On an argument that the answer to the question whether a machine "works" depends on actors' interpretations of the machine itself, see Donald MacKenzie, "How Do We Know the Properties of Artefacts? Applying the Sociology of Knowledge to Technology," in Technological Change: Methods and Themes in the History of Technology, ed. Robert Fox (Amsterdam, 1995), 247-63. On the roots of contemporary antideterminist trends in the historiography of technology, see Bijker, Hughes, and Pinch, 1-6. 


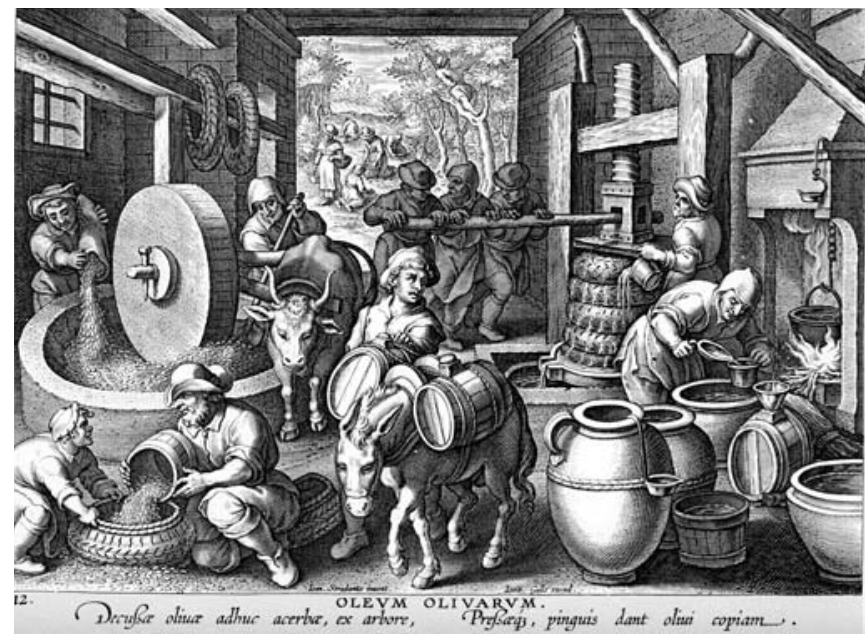

FIG. 1 Traditional oil making. (Johannes Stradanus [Jan van der Straet], Nova Reperta [Antwerp, circa 1600].)

The design of modern oil-manufacturing machinery resulted not from any independent technological trajectory but from negotiations about who should benefit from oil production, and how. ${ }^{5}$

5. The most relevant body of literature devoted to modern olive oil technology has been produced by scholars working on the evolution of agricultural tools and techniques in southern France, most notably Antoine Casanova; see his Paysans et machines à la fin du XVIIIe siècle: Essai d'ethnologie historique (Paris, 1990), or, for a broader overview, Marie-Claire Amouretti and Georges Comet, eds., L'évolution des techniques est-elle autonome? (Aix-en-Provence, 1991). Drawing on the Marxian treatment of the relation between machinery and labor processes, Casanova describes machines as elements of the "productive forces," which include artifacts, skills, training, and social relations. In this sense, machines are always part of a "structured totality," or milieu technique (Casanova, 317; the term derives from André Leroi-Gourhan, Milieu et techniques, 2 vols. [Paris, 1943-45]). This suggestive contextual analysis coexists with an essentially deterministic model of technical change. Casanova concedes that the social structure can modify "the rhythm of the evolution of the productive forces," but contends that it does not shape those forces in any deeper sense. What needs to be explained, he writes, are the "unequal rhythms of development in different regions." He refers to "obstacles" that delayed the "progress of the productive forces" in oil manufacture, such as feudal rights concerning milling; in that specific case, Casanova argues that feudal seigneurs preserved "bad machinery," neglecting its "technological shortcomings"; that their mills had "insufficient power"; that the oil extracted was "mediocre"; and that new machines had "better technical features." See Paysans et machines, 10, 12, and Antoine Casanova, Techniques, société rurale et idéologie en France à la fin du XVIII siècle (Paris, 1978), 25, 32. Similar arguments can be found in Charles Parain and Pierre Vilar, "Mode de production feodal et classes sociales en système precapitaliste," Les Cahiers du Centre d'Études et de Recherches Marxistes 59 (1968): 1-38. Working from this perspective, one can, to quote Donald 


\section{The Business of Olive Oil}

Oil production and trade spanned the centuries since the beginning of Mediterranean civilization. The oil mills and presses of 1750 resembled some of the machines used in antiquity. That is not to say that technology had stagnated. ${ }^{6}$ Archaeological and ethnographic research has documented

APRIL

2004

VOL. 45 the continuously changing forms of oil-production machinery. ${ }^{7}$ And always, changes in the socioeconomic setting of the oil-producing regionssuch as a shift to large-scale production for export—shaped technological developments. ${ }^{8}$

This basic process of intertwined social, economic, and technological change is in no way unidirectional. In the late Roman empire, for instance, with trade declining on the Mediterranean routes, provinces once renowned for their exports began to rely more on local consumption, and producers in those areas turned from comparatively sophisticated technology back to simpler alternatives. Northern Syria provides a good example. ${ }^{9}$ As trade declined in the fourth and fifth centuries C.E. and the population grew, property parcels shrank and the vast estates devoted to oil production for export were dismantled. Oil producers gradually abandoned the molae oleariae - elaborate oil mills typically associated with the latifundia, slavery, and the trading economy-in favor of smaller and cheaper mills. The families who ran the new mills had little money to invest in machinery construction and maintenance, nor could they afford to buy timber, which Syria lacked. They aimed to produce oil exclusively for local consumption.

MacKenzie, consistently "accept that the pace of technical change was affected by social relations ... while denying that those relations affected the actual design of technical artifacts"; see "Marx and the Machine," in Knowing Machines: Essays on Technical Change (Cambridge, 1998), 44. On the theoretical relevance to the Marxian perspective of the evolution of mills, see Karl Marx, Capital: A Critique of Political Economy, vol. 2 (London, 1990), chapter 15, and Casanova, Paysans et machines, 7-10. See also Marc Bloch, "Avènement et conquête du Moulin à eau," Annales d'histoire économique et sociale 8 (1935): 538-635; Bertrand Gille, "Le Moulin à eau, une révolution technique médiévale," Techniques et civilisations 3 (1954); and Charles Parain, Outils, ethnies, et développement historique (Paris, 1979), 305-29. For a similarly deterministic treatment of an eighteenth-century productive technology, in which technological progress is said to be inhibited or favored by certain political and economic conditions, see Brian Peckham, "Technological Change in the British and French Starch Industries, 1750-1850," Technology and Culture 27 (1986): 18-39.

6. Yves Pehaut, Les oléagineux dans le monde (Paris, 1986), 121.

7. Marie-Claire Amouretti, "Blocage des techniques antiques ou blocage des historiens sur ces techniques?” Études Corses 46-47 (1996): 235-51.

8. The pioneering study is Aage G. Drachmann, Ancient Oil Mills and Presses (Copenhagen, 1932). See also Jean-Pierre Brun, L'oléiculture antique en Provence: Les huileries du département du Var (Paris, 1986); Marie-Claire Amouretti, Oil and Wine Production in the Mediterranean Area (Paris, 1993); and Rafael Frankel, Wine and Oil Production in Antiquity in Israel and Other Mediterranean Countries (Sheffield, 1999).

9. Olivier Callot, Huileries antiques de Syrie du nord (Paris, 1984); see also Georges 
The result was the success and diffusion of a rudimentary new millingpressing system that involved simply rolling a cylindrical stone over the olives. ${ }^{10}$

The modern golden age of olive oil began around 1750. Increasing consumption of oil for cooking and eating was only one factor accounting for growing demand and rising prices; industrial uses, which included lighting, lubrication, and the manufacture of soap and wool, also played an important part. ${ }^{11}$ Responses to this increasing demand varied significantly throughout Mediterranean Europe.

One can divide the oil-producing regions of Europe into three main sociotechnical landscapes. The rural areas of Corsica, Portugal, and parts of southern Italy were characterized by self-sufficient local economies and communal systems of land ownership, and in these areas infrastructure and machinery were shared and jointly owned. In the feudal lands of rural Provence and southern Italy, royal, feudal, and communal rights over land and machinery tended to concentrate in the hands of a few individuals or institutions, and their competing claims often came into conflict. Finally, in the bourgeoisie-controlled trading centers of the French and Italian Rivieras, such as Aix, Marseilles, Nice, Genoa, and Lucca, ownership of land and machines granted individuals control over the entire manufacturing process. It was in this last setting that the opportunity offered by the growing demand for olive oil found well-organized elites ready to profit from it.

Mid-eighteenth-century French and Italian landowners invested consistently in the cultivation of olive trees and the production of oil. ${ }^{12}$ The era also saw the publication in France, Italy, and Portugal of a number of books and shorter works on modern oil manufacture. ${ }^{13}$ These portrayed existing prac-

Tate, Les campagnes de la Syrie du Nord du Ie au VIIe siècle: Un exemple d'expansion démographique et économique dans les campagnes à la fin de l'antiquite, vol. 1 (Paris, 1992).

10. Callot, 20-23. For another case of technological reversion, see Noel Perrin, Giving Up the Gun: Japan's Reversion to the Sword, 1543-1879 (Boston, 1979). See also Donald MacKenzie, "Theories of Technology and the Abolition of Nuclear Weapons," in The Social Shaping of Technology, ed. Donald MacKenzie and Judy Wajcman (Buckingham, 1999), 419-42.

11. In the 1790 s a combination of war and bad crops precipitated a crisis in the olive oil industry, which became structural with the appearance of cheaper mineral oils. For a socioeconomic analysis of the oil crisis in southern Italy, see Aurelio Lepre, "Una crisi olearia verso la fine del Settecento," in Aurelio Lepre, Contadini, borghesi ed operai nel tramonto del feudalesimo napoletano (Milan, 1963), 243-68.

12. In the coastal areas of Calabria, for instance, landlords systematically replaced mulberry trees and other arboreal cultures with olive trees. See Augusto Placanica, Storia dell'olio d'oliva in Calabria dall'antichità ai giorni nostri (Corigliano Calabro, 1999), $115-17$.

13. Lazare Sieuve, Mémoire et journal d'observations et d'expériences sur les moyens de garantir les olives de la piqure des insectes: Nouvelle méthode pour en extraire une huile plus abondante et plus fine, par l'invention d'un Moulin domestique, avec la manière de la garantir de toute rancissure (Paris, 1769); Domenico Grimaldi, Istruzioni sulla nuova 
tices and machines as products of scientific ignorance, barbarian customs, and medieval law-truly a heritage of the dark ages. In 1782 the Académie des Sciences, Lettres et Arts of Marseilles offered a prize for a treatise on the cultivation of olive trees "and the best way to extract oil from olives" that generated an unprecedented number of responses. ${ }^{14}$ The Accademia dei Georgofili in Florence, the agricultural society of Aix, and the royal academies of science of Naples and Lisbon also began to support similar research. ${ }^{15}$

These developments occurred in the context of a more general reform movement in agriculture and manufacturing. Reformers saw this effort as a process of rationalization that derived directly from the scientific tradition of the Encyclopédie, and as their patriotic contribution to their countries' economic well-being. ${ }^{16}$ They identified as basic conditions for pro-

manifattura dell'olio introdotta nel Regno di Napoli (Naples, 1777); François Rozier, "Vues économiques sur les moulins et pressoirs a l'huile d'olives, connus en France ou en Italie," Observations sur la physique, sur l'histoire naturelle et sur les arts 8 (1776): 417-43; François Rozier, Cours complet d'agriculture, théorique, pratique, économique, et de médicine rurale et vétérinaire, 10 vols. (Paris, 1783-1800), s.v. "huile" and "olivier"; Pierre Joseph Amoreux, Traité de l'olivier (Montpellier, 1784; reprint, Nîmes, 1990), and Mémoire sur la nécessité et les moyens d'améliorer l'agriculture dans le district de Montpellier (Montpellier, [1795]); Joaõ Antonio Dalla Bella, Memórias e observações sôbre o modo de aperfeiçoar a manefactura [sic] do azeite de oliveira em Portugal (Lisbon, 1784); Abbé Couture, Traité de l'olivier (Aix, 1786; reprint, Nîmes, 1996); Pons-Joseph Bernard, Mémoire pour servir à l'histoire naturelle de l'olivier (Marseille, 1788; reprinted in part in Casanova, Techniques [n. 5 above], 59-166); Cosimo Moschettini, Osservazioni intorno agli ostacoli de' trappeti feudali alla prosperità della olearia economia (Naples, 1792); Bartolomeo Gandolfi, Saggio teorico-pratico sopra gli ulivi, l'olio e i saponi (Rome, 1793); Giovanni Presta, Trattato degli ulivi, delle ulive, e della maniera di cavar l'olio, o si riguardi di primo scopo la massima perfezione, o si riguardi la massima possibile quantità del medesimo (1794), in Giovanni Presta, Opere, vol. 2 (Lecce, 1988). A few technical novelties appeared in eighteenth-century Spain, such as the rulas, a pair of millstones shaped like conic trunks, but no traces exist of any significant campaign for the mechanization of oil manufacture there. See Agricultores, botánicos y manufactureros en el siglo XVIII: Los sueños de la Ilustración española (Madrid, 1989), 146-49.

14. In 1766 the Société Royale des Sciences of Montpellier had asked for treatises on the best way of making and preserving olive oil, but the response had not been particularly remarkable. See Mémoire sur la culture de l'olivier et la manière d'extraire l'huile des olives: Pour servir de réponse à la question proposée par l'Académie des Belle-Lettres, Sciences et Arts de Marseille, pour le sujet du Prix de 1782 (Aix, 1783), 43.

15. Marie-Claire Amouretti, "Des agronomes latins aux agronomes provençaux: Les moulins à huile," Provence historique 31 (1981): 83-100.

16. See, for instance, Presta, 10. Giovanni Presta (1720-97), from Gallipoli, in Apulia, was a renowned physician and agronomist and an enlightened landowner. Giovanni Targioni Tozzetti (1712-83) also typifies these practical-minded Enlightenment reformers. A physician and a member of the Accademia dei Georgofili of Florence, Tozzetti explicitly sought to establish a "philosophical theory" of agriculture and manufacture to end the reliance on "popular practices." What he wanted was "a new method to study agriculture" based on mathematics, physics, and natural history. See Giovanni Targioni Tozzetti, Ragionamenti sull'agricoltura toscana (Lucca, 1759), vi-vii, 1-27. 
gress first the recognition of full, exclusive rights of ownership over land, and second, the rationalization of production-meaning mechanization, standardized procedures, and work discipline. Thus, the Enlightenment emerged in the Mediterranean lands first of all as an urge for technical innovation. But one should not lose sight of the political and social concerns that informed the material and literary productions of the southern Enlightenment. The alleged neutrality of these pragmatic concerns (prices, taxes, grain trade, oil mills) should be understood in relation to the prevailing cultural conditions. In many southern European societies, reformers had only a very limited capacity to mobilize resources in support of modernization. The strategic use of technical discourse could, in such circumstances, undermine the foundations of the sociopolitical system without directly attacking traditions. Their awareness of their weak social position explains why southern entrepreneurs repeatedly sought government help, either in the form of credit or in the form of institutions to foster production and technical education, even as they defended laissez-faire principles. What they were asking for was state-controlled economic liberalization, guided by the tenets of the new enlightened rationalism.

Whether they were active in provincial economic societies, managing their own farms, or writing pamphlets in a capital city like Naples or Lisbon, reformer-entrepreneurs shared a way of thinking and a set of basic beliefs. ${ }^{17}$ In particular, they believed in the power of analysis. This term had a very broad meaning in the eighteenth century: it indicated a savoir faire, a way of representing reality and intervening in it. Analytic rationality included different but related kinds of cultural resources, skills, and procedures, among them problem-solving techniques based on the resolution-composition of ideas, the mechanization of thinking according to combinatorial rules of algebra, and the study of economic issues on the basis of individual and collective utility. It provided a unitary and universally valid framework in which subjects ranging from mathematics to human biology, the structure of society, or the distribution of labor in a mill could be understood. Mathematicians had shown that solving a differential equation required breaking it down to its component terms and then solving each one independently, according to formal rules. In similar fashion, reformers began searching for the elementary units and basic operations of their own fields. ${ }^{18}$

17. The boundaries between the categories entrepreneur, agronomist, and reformer were extremely blurred. The enlightened scientist-entrepreneur was indeed a typical figure in eighteenth-century agricultural reform. See, for instance, Jerry B. Gough, "Winecraft and Chemistry in 18th-Century France: Chaptal and the Invention of Chaptalization," History of Technology 39 (1998): 74-104. On the French provincial academies, see Daniel Roche, Le siècle des lumières en province: Académies et académiciens provinciaux, 1680-1789, 2 vols. (Paris, 1978).

18. On the politics of eighteenth-century mathematical analysis, see Eric Brian, $\mathrm{La}$ mesure de l'état: Administrateurs et géomètres au XVIIIe siècle (Paris, 1994), and Massimo 
Who were these reformers? They varied in social and cultural background. Some were proprietors of great estates who, following the example of the English landed aristocracy, aimed to modify land use customs. Others were bourgeois entrepreneurs willing to risk their wealth in a new kind of speculation. Others were civil servants, enlightened bureaucrats interested in the experimental sciences, and members of scientific acade-

APRIL

2004

VOL. 45 mies. Let us consider three representatives, taken from Italy, France and Portugal.

In Italy much of the literature on olive oil production came from the Kingdom of Naples, where it was by far the single most important export. Oil was the main source of revenue in the provinces of Apulia and Calabria, in parts of which the cultivation of olive groves amounted to monoculture. Unlike certain Provençal and northern Italian oils, the southern product was not considered to be of high-quality (olio fino). In the 1760 s a desire to enter the profitable market for olio fino pushed reformers in Apulia and Calabria to study oil production and support modernization. The Marquis Domenico Grimaldi (1735-1805), a member of an old Genoese patrician family, led their campaign. The interests of the Grimaldis were divided between two very different worlds: the trading centers of the French and Italian Rivieras on the one hand, and the feudal-communal lands of Calabria on the other. Because of their international connections and trading skills, the Grimaldis were in a better position to perceive and react to favorable economic conditions than the Calabrian aristocracy. In the 1760s the reform movement in Naples was strong, the cultural atmosphere favored change, prices were rising, and good-quality oil offered higher profits than any other type of agricultural venture in Calabria. The Grimaldis decided to invest heavily in the modernization of oil manufacture. ${ }^{19}$ By 1765 Domenico was administering a family estate near Genoa and traveling through Provence, Switzerland, and Northern Italy to study agricultural techniques, tools, and machines. A few years later he was back in Calabria,

Mazzotti, "The Geometers of God: Mathematics and Reaction in the Kingdom of Naples," Isis 89 (1998): 674-701. On analytic rationality in engineering and manufacture, see Antoine Picon, L'invention de l'ingénieur moderne: L'Ecole des Ponts et Chaussées, 1747-1851 (Paris, 1992); Ken Alder, Engineering the Revolution: Arms and Enlightenment in France, 1763-1815 (Princeton, N.J., 1997); and Massimo Mazzotti, "Le savoir de l'ingénieur: Mathématique et politique à Naples sous le Bourbon," Actes de la recherche en sciences sociales 141/142 (2002): 86-97.

19. On Neapolitan reformism, see Franco Venturi, "La Napoli di Antonio Genovesi," in Settecento riformatore (Turin, 1998), 1:523-644, and Giuseppe Galasso, La filosofia in soccorso de' governi: La cultura napoletana del Settecento (Naples, 1989). For a selection of writings by Neapolitan reformers, see Franco Venturi, ed., Illuministi italiani, vol. 5, Riformatori napoletani (Milan, 1962), which includes a biographical essay on Grimaldi (411-30). On Grimaldi, see also Antonio Basile, "Un illuminista calabrese: Domenico Grimaldi da Seminara," Archivio storico per la Calabria e la Lucania 13 (1943): 16-156, and Domenico Luciano, ed., Domenico Grimaldi e la Calabria nel '700 (Assisi, 1974), xi-lvii. 
promoting such innovations as the cultivation of citrus fruits, a new plow design, a new type of irrigation system, and a new silk-throwing process. ${ }^{20}$ Meanwhile he turned out a series of essays on the modern manufacture of olive oil (which he called "Genoese manufacture"), addressing them to southern landowners, investors, and politicians. ${ }^{21}$

In France, technical change was also championed by scientifically minded agronomists to whom oil manufacture was but one aspect of the general problem of the modernization of agriculture. They included gentilshommes agronomes as well as men of more humble origin employed at some level of public administration. ${ }^{22}$ The Journal de l'agriculture, du commerce et des finances (Paris, 1765-83), François Rozier's Cours complet d'agriculture and his Journal de Physique (Paris, 1773-93), and Despommiers's L'art de s'enrichir promptement par l'agriculture prouvé par des experiences (Paris, 1762), were among the key publications of the movement for agricultural reform. Pons-Joseph Bernard's Mémoire pour servir à l’histoire naturelle de l'olivier (1788) was another. Born near Draguignan, in Provence, Bernard (1748-1816) joined the Oratorian order in 1764. Nine years later he left the path to the priesthood and decided to devote himself to scientific studies and a career in public administration. He first became director of the royal navy observatory in Marseilles. In 1780 he was employed by the regional government of Provence to oversee engineering problems related to the modification of the course of the river Durance. In 1790 he was named administrator of the department of Var and a member of the Directoire. He became chief engineer for Var, and a corresponding member of the Académie Royale des Sciences in Paris. Along with his scientific papers in mathematics, astronomy, and hydraulics, Bernard published works on natural history and agronomy, and his Mémoire pour servir à l'histoire naturelle de l'olivier provided a detailed description of modern oil manufacture. His arguments therein, he wrote, were built on the "immense progress of mechanics and physics." He dismissed earlier authors as lacking either empirical knowledge of the natural features of Provence, or experi-

20. Domenico Grimaldi, Saggio di economia campestre per la Calabria Ultra (Naples, 1770; reprinted in Luciano, 1-175). Grimaldi was a corresponding member of the Société Royale d'Agriculture of Paris and of the Ökonomische Gesellschaft of Berne, to which he sent an essay on the cultivation of a new kind of grass for artificial fields; Venturi, Riformatori napoletani, 414.

21. Grimaldi, Istruzioni sulla nuova manifattura dell'olio (n. 13 above). See also Domenico Grimaldi, Memoria per lo ristabilimento dell'industria olearia e della agricoltura nelle Calabrie ed altre provincie del Regno di Napoli (Naples, 1783), and Memoria sulla economia olearia antica e moderna e sull'antico frantojo da olio trovato negli scavamenti di Stabia (Naples, 1783).

22. André Bourde, Agronomie et agronomes en France au XVIIIe siècle (Paris, 1967), 1561-608. See also Jean Boulaine, "Vingt ans de vulgarisation trop exclusive, 17851805," in Marie-Claire Amouretti and François Sigault, Traditions agronomiques européennes: Élaborations et transmission depuis l'antiquité (Paris, 1998), 53-63. 
mental skills, or modern scientific knowledge, which included both "la physique de l'olivier" and "la physique des machines."

In Portugal, reform was supported by a group of intellectuals very close to the government, the so-called estrangeirados. The term referred both to foreign scholars and to Portuguese who had spent part of their professional careers abroad. The reform government of the Marquis of Pombal charged

APRIL

2004

VOL. 45 the estrangeirados with modernizing the teaching of science and applying modern scientific knowledge to the solution of Portugal's economic problems. ${ }^{23}$ The main Portuguese work on modern oil manufacture was written by Giovanni Antonio Dalla Bella (1730-1823), an Italian lecturer on experimental physics from the University of Padua who joined the Collegio Real dos Nobres of Lisbon in 1767. In 1772, in the context of Pombal's university reform, Dalla Bella moved his cabinet of experimental physics to the new royal university in Coimbra. ${ }^{24} \mathrm{~A}$ few years later he also became a member of the Academia Real das Sciencias of Lisbon, founded with the explicit purpose of using modern scientific knowledge to stimulate the economic growth of the country. ${ }^{25}$ Most representative of the activity of this academy were the contributions collected in the Memórias económicas, published from 1789 on. ${ }^{26}$ Among Dalla Bella's own agronomic publications were essays on the manufacture of olive oil and the culture of olive trees. ${ }^{27} \mathrm{Nisi}$ utile est quod facimus, stulta est gloria was the epigraph for the Memórias económicas in 1789. Three years later the Apulian reformer Cosimo Moschettini would open his essay against feudal rights to oil manufacture with exactly the same words. ${ }^{28}$

23. On the scientific and cultural role of the estrangeirados, see Ana Simões, Ana Carneiro, and Maria Paula Diogo, "Constructing Knowledge: Eighteenth-Century Portugal and the New Sciences," in The Sciences in the European Periphery during the Enlightenment, ed. Kostas Gavroglu (Dordrecht, 1999), 1-40.

24. On Dalla Bella's scientific activity, see Dizionario biografico degli italiani, s.v. "Dalla Bella, Giovanni." On experimental physics in Portugal, see Rómulo de Carvalho, "A Física na Reforma Pombalina," in Actividades Científicas em Portugal no Século XVIII (Evora, 1996), 605-30.

25. Esteves Pereira, "Economia em Portugal no século XVIII: Aspectos de mentalidade," Prelo 2 (1984): 25-40; José Luís Cardoso, O pensamento económico em Portugal nos finais do século XVIII, 1780-1808 (Lisbon, 1989), 35-123; Jacinto Nunes, "A contribução das Memórias Económicas para o desenvolvimento científico e económico do país," in História e desenvolvimento da ciência em Portugal (Lisbon, 1992), 2:1341-51. On the specific features of the Portuguese agricultural system, see Albert Silbert, Le Portugal Méditerranéen à la fin de l'ancien régime, XVIIIe-début du XIXe siècle: Contribution a l'histoire agraire comparée (Paris, 1966).

26. José Luís Cardoso, ed., Memórias económicas da Academia Real das Ciências de Lisboa, para o adiantamento da agricoltura, des artes e da indústria em Portugal, e suas conquistas, 1789-1815 (Lisbon, 1990). For biographical information on the academics, see Moses B. Amzalak, A economia politica em Portugal: O fisiocràtismo-as Memórias Económicas da Academia e os seus colaboradores (Lisbon, 1922).

27. Dalla Bella, Memórias e observações (n. 13 above), and Memória sôbre a cultura das oliveiras em Portugal (Coimbra, 1786).

28. "If what we do is not useful, [our] glory is foolish." The same incipit opened the 


\section{Traditional Oil Manufacture}

The production of olive oil involved a few basic steps: olives were collected, stored, milled, and pressed, with the oil then left to clear in special containers. Traditional animal- or water-powered oil mills used a vertical millstone that turned on a metal pivot around a vertical axle and rolled upon another circular stone (the dormant stone), horizontally placed, crushing the fruit by simple pressure (although certain Roman mills ground the fruit). Mill buildings and materials varied from region to region, as did the design of the various parts of the mechanism.

In Calabria, olives were crushed in the trappeto. ${ }^{29}$ This machine was located in a large building, also called a trappeto, where the olives were stored in great baskets (cestoni) or wooden cupboards (zimboni). The typical Calabrian trappeto used a vertical millstone approximately 5 Neapolitan palmi in diameter and measuring 1.5 palmi on its edge ( 1 palmo equals 0.253 meters). ${ }^{30}$ The dormant stone was often concave, like a basin, so that the millstone made only partial contact with it. A mule supplied power, while a man fed the olives into the stone with a spade. In Apulia, millstones were bigger ( 6 to 8 Neapolitan palmi in diameter), heavier, and rolled on a flat dormant stone. The edge of the millstone was rounded, reducing the contact surface by two-thirds and increasing the force applied at the point of contact. A circular basin surrounded the dormant stone, and a man moved the olives from the basin back under the stone repeatedly until they were ready for pressing. The Apulian oil mill was carved into the rock, a few meters underground. ${ }^{31}$ This type of mill was widespread in southern Apulia because of its relatively inexpensive construction and the insulating properties of stone (warmth being a crucial factor in oil production). Rivers are rare in Apulia, so mills there were animal-powered. By comparison, traditional Provençal mills use smaller millstones and were powered either by a horse (moulin à sang) or by a waterwheel (moulin à eau). Mills of the latter type used a horizontal wheel placed under the dormant stone and turning around the same axle as the millstone.

Pressing offered a wider spectrum of technical possibilities. Four basic types of oil presses were in use around 1750, each with endless local varia-

Memórias da Academia Real das Sciencias [sic] de Lisboa, vol. 1, Desde 1780 até 1788 (Lisbon, 1797).

29. The trapetum was a Roman oil mill, of a very different design. See G. Arrighi, "Notizia di un frantoio pompeiano per olive," Klearchos 19 (1963): 83-86.

30. Carlo Afan de Rivera, Tavole di riduzione dei pesi e delle misure delle Due Sicilie in quelli statuiti dalla legge del 6 aprile 1840 (Naples, 1840).

31. A wealth of folklore surrounded Apulian underground mills and the oil-making process. The sciacuddri, a spiteful gnome who inhabits a mill, is a common figure in the folklore of most oil-producing regions. See Antonio Monte, Frantoi ipogei del Salento (Lecce, 1995), 36-37. On the operation of underground, or hypogeal, mills, see also Lucia Milizia Fasano, Il trappeto sotterraneo in Terra d'Otranto (Lecce, 1991). 
tions. ${ }^{32}$ Torsion presses were common in Corsica and southern Italy. ${ }^{33}$ In this type of press, very ripe olives were put in a large sack made of goat hair, which was then pushed into place in a wooden trough. Two people then twisted the sack using a pair of sticks, forcing oil from the olives, which collected in the trough and drained into a receptacle. Each sack of olives would

APRIL

2004

VOL. 45 be pressed in this way several times, with hot water being used at the end to help extract the last remnants of oil from the fruit.

The beam press (presse à arbre) was common in southern France. In its basic form this consisted of a long wooden lever, one end pinned in a recess in a wall or between two pillars, while the other could be pulled down to exert pressure on whatever was under the lever, or beam-in this case, a bag of olive paste. The sacks used with this type of press were made of vegetable fiber to allow the oil to pass through them. In the most archaic examples, the lever was forced downward by a great stone (350-400 kilograms). Beam presses were in use in the Aegean world before 1000 B.C.E. and could be found in Corsica as late as the nineteenth century. A more complex variation included the use of a capstan, which lifted a counterweight. The lever could also be forced down with the aid of screws. In the first edition of the Encyclopédie, Diderot praised a counterbalanced lever-and-screw press common in Provence and Languedoc, called the pressoir à gran banc or "Greek press," and recommended its use in the manufacture of olive oil. Another variation was the pressoir à taissons, depicted in Louis Liger's Maison rustique (1749), in which the screw was fixed to the ground. ${ }^{34}$ Screws, capstans, and bascule levers could be employed to increase the amount of force exerted by the press without increasing the amount of force required to operate it. Indeed, the limited need for power and the continuous action of the lever were well-known advantages of these presses. Dalla Bella describes a lever-and-screw press from the region of Coimbra, Portugal, in which the free end of the lever was forced down by means of a wooden screw fixed to a stone. ${ }^{35}$ Some of these Portuguese lever-and-screw presses continued to operate into the twentieth century. ${ }^{36}$ A very similar type of press was common in Andalucia, Spain. ${ }^{37}$

32. Charles Parain, "Typologie des pressoirs pré-industriels et aires de diffusion des types successifs en Europe occidentale," in VI Congrès International des Sciences Anthropologiques et Ethnologiques (Paris, 1960).

33. Casanova, Paysans et machines (n. 5 above), described the use of this archaic press in eighteenth-century Corsica. On similar presses in southern Italy, see Presta (n. 13 above), 401-5.

34. Louis Liger, La nouvelle maison rustique ou économie générale de tous les biens de campagne (Paris, 1749).

35. Dalla Bella, Memórias e observações (n. 13 above), 50-51.

36. This was the case for the mills of Idanha a Velha and Enxabarda, in the district of Castelo Branco. See Marie-Claire Amouretti et al., "À propos du pressoir à huile: De l'archéologie industrielle à l'histoire," Mélanges de l'École Française de Rome-Antiquité 96 (1984): 379-421.

37. A lever-and-screw press (prensa de viga y quintal) from the oil-producing region 
The other most common kind of press, the screw press, worked by means of the direct action of one or two screws. Like the lever press, the main variations of the screw press can be traced back to classical sources, which described its use in wine making and oil production. The doublescrew press, in which a wooden beam is forced downward by two fixed screws, was found all over southern Italy, along the Adriatic coasts, and on some Greek islands. It was often referred to as "Calabrian press." Central screw presses were relatively common in northern Italy and Provence. They could vary greatly in size, force exerted, and structure. One problem with this type of machine was that the upper beam and the two lateral pillars broke down rather easily. Mid-eighteenth century agronomists agreed that a sophisticated bascule lever-and-screw press was on the whole superior to the central screw press. $^{38}$

Reformers portrayed this technological congeries as chaotic and irrational, and argued that new machines could extract oil in the most rational and effective way. Grimaldi offers a representative example. He described three basic advantages to modern oil-manufacturing technology: it was cheaper, meaning more mills distributed more rationally in the landscape; it produced more oil from of the same amount of olives in less time; and it produced better oil. Like Bernard and Dalla Bella a few years later, Grimaldi presented the adoption of new technology as a simple and straightforward matter, the natural outcome of the application of modern science to agriculture and manufacturing.

In the traditional Mediterranean landscape oil mills were among the most conspicuous signs of feudal power. ${ }^{39}$ They required considerable investment to build and operate, and returned a profit only if numerous small and medium-sized producers brought their olives for processing (in Apulia, the common phrase was the "mill's dowry"). This meant enforcing the feudal jus prohibendi, or right of excluding others, either by the lord or by communal authorities. In 1792 the Apulian reformer Cosimo Moschettini published an essay arguing that the jus prohibendi impeded the diffusion of modern manufacturing, because entrepreneurs could not build their own mills, while feudal lords had no interest in making their mills more efficient. Bernard wrote about the same problem, which in Provence took the form of a monopoly over oil milling conferred on a seigneur by the right

of Jaen has been recently reconstructed and described in some detail. José Ignacio Rojas Sola, Estudio histórico-tecnológico de molinos y prensas para la fabricación de aceite de oliva: Aplicación al estudio en detalle y reconstruction gráfica de una prensa de viga y quintal (Jaén, 1997).

38. See Rozier, "Vues économiques sur les moulins" (n. 13 above), 426-28, on the technical properties of the pressoir à martin.

39. In Apulia, for instance, oil mills were typically built in or near the feudal manor: the Marquis Granafei had fourteen oil mills on his estate at Sternatia, while the lord of Melpignano had seven oil mills in the subterranean mill of his castle. See Monte (n. 31 above), 47. 
of banalité, which obliged inhabitants of the seigneury to use the mill. During the second half of the eighteenth century this monopoly became the subject of heated disputes. The community of La Fare, for example, which had conceded this right to the local seigneur in 1709 , went through a longdrawn-out trial (1758-66) to regain it. Technical questions about oil-manufacturing machinery played a crucial role in the legal battle, as it emerged

APRIL

2004

VOL. 45 that the farmers who brought their olives to the mill had come to regard the traditional manufacturing process as gravely inadequate. ${ }^{40}$

The first advantage that reformers attributed to modernized oil manufacture, then, namely the diffusion of privately owned mills, conflicted with the interests of the great absentee landowners. These interests did not neatly coincide with those of the landed aristocracy. While historians have correctly emphasized the differences between feudatories and bourgeois entrepreneurs, the distinctions between these categories sometimes blurred. In Southern Italy, for example, the bourgeoisie could grow in the shadow of the feudal system without attacking it as a whole, profiting instead from the opportunities it offered for attractive low-risk investment. Entrepreneurs often found it profitable to invest in-and so to reinforce-an absentee mode of production, mainly by selling credit to impoverished tenant farmers and speculating in cereals and oil. ${ }^{41}$

\section{New Proprietors, New Machines, New Oil}

Why was it that in the mid-eighteenth century feudal mills and traditional oil production came under criticism as inefficient? To answer this question we need to scrutinize descriptions of the machines involved and of the quality of the final product. This means shifting our analysis to the level of design.

Grimaldi carefully recorded his investigations into oil production. These invariably confirmed the technical superiority of modern technology, which he attributed to the fact that modern machinery was more powerful. Like Bernard, Grimaldi criticized traditional millstones as too small, too light, and badly cut. The olive paste produced by these stones contained pieces that were too large, making oil extraction more difficult and less efficient. To improve the crushing action, Grimaldi advocated first changing

40. Moschettini (n. 13 above). Mireille Bourgey, "Un cas de réaction féodale: La banalité du moulin à huile de La Fare," Provence historique 12 (1962): 309-33. See also Michel Derlange, "Olivier, huile et gestion communale en Provence orientale sous l'Ancien Régime," Provence historique 31 (1981): 113-25.

41. On the development of the southern Italian bourgeoisie, and on their investing strategies, see Lepre (n. 11 above); Patrick Chorley, Oil, Silk, and Enlightenment: Economic Problems in XVIIIth Century Naples (Naples, 1965); and John Davies, Merchants, Monopolists, and Contractors: A Study of Economic Activity and Society in Bourbon Naples, 1815-1860 (New York, 1981). 
the dimensions of the millstone. In place of the traditional ratio between edge and diameter of around three to ten, he proposed a ratio of one to ten; and rather than cut the stone so that it was approximately as thick at the edge as at the center, he thought the stone should taper along its radius to a narrower edge. These changes would entail others: to facilitate the crushing action of the thin-edged stone the basin should be redesigned to resemble a well opening, with vertical walls surrounding a flat dormant stone, and the man who fed olives to the millstone could be replaced by a metal device (called mescia by the Genoese) that pushed olives under the stone at each revolution of the stone around the axle.

Would a new mill built along those lines indeed extract more oil from the same amount of olives? New machines worked better only for those who shared certain new assumptions, and in fact reformers did not want merely to produce more oil. Prices could be increased and new markets created only by changing the nature of the product and widening the range of possible uses. Entrepreneurs wanted to invest in the manufacture of highquality oil (olio fino, huile vierge, azeite fino), which could be sold on international markets at up to double the price of common oil. At midcentury, the centers of production of high-quality oil were Provence (Aix), the Italian Riviera (Genoa, Oneglia), and Tuscany (Lucca). Among the characteristics that distinguished their oils from those made in the rest of the Mediterranean basin the most important was their low acidity. They were also more transparent, sweeter, and, crucially, much easier to preserve. Changes in external conditions affected common oil more readily, and it began to turn rancid after a comparatively short period of time. And when oil became rancid it lost not only its original flavor but also the other physical characteristics that made it valuable. At best it could be shipped to Marseilles to be used for soap making. As international demand steadily grew, the main concern for producers and traders became not the supply but rather the quality of the product. ${ }^{42}$

High-quality oil not only lasted longer than common oil, which made it more desirable for long-distance trade; it also burned more efficiently in lamps and made a better lubricant for clockworks. ${ }^{43}$ Most of all, low-acidity olive oil worked better than any other known material as a lubricant for industrial machinery. It spread easily and thoroughly over surfaces, and it did not congeal, taking up to seven days to gain as little as 1.7 percent of its

42. The beginning of the mass production of olio fino in the Genoese Riviera can be dated to the third decade of the eighteenth century. See Grimaldi, Istruzioni sulla nuova manifattura dell'olio (n. 13 above), 106.

43. Oil lamps diffused rapidly throughout Europe in this period, particularly after the introduction of the annular wick in 1782. On the extensive use of olive oil for lubricating clocks, see Charles K. Aked, "Oil for Chronometers," Antiquarian Horology 5 (1968): 454-55, and David S. Landes, Revolution in Time: Clocks and the Making of the Modern World (Cambridge, Mass., 1983), 132-44, 171-76. 
weight after exposure to the air. Because of its viscosity and oiliness, olive oil worked extremely well under pressure: it maintained coefficients of friction between 0.07 and 0.08 between wood surfaces, metal surfaces, or a combination of the two. This meant that, given the relatively low rotational speed of English machinery before the turn of the nineteenth century, olive oil could endure great stress without decomposing. ${ }^{44}$

APRIL

2004

VOL. 45

Reformers did not refer directly to the industrial uses of olive oil. Rather, they framed the modernization of oil production as a project of national economic reform, stressing the local uses of high-quality oil in lighting, cooking, and medicine..$^{45}$ They placed great emphasis on the superior taste of low-acidity oil, and on its beneficial health effects. But the high price of low-acidity oil betrays the deception at the core of these tracts. In reality, modernized production would force local peasants to consume cheaper by-products instead of the oil to which they were accustomed. Meanwhile, a taste for low-acidity olive oil became a mark of the affluent Mediterranean bourgeoisie. ${ }^{46}$

The new marketing strategies of olive oil producers and traders must have been evident to anyone visiting a major Mediterranean oil port. Gallipoli, in Apulia, offers a revealing example. By the 1780s most Apulian oil was shipped abroad through this small coastal town. On a clear day its harbor might easily contain seventy foreign vessels waiting for a load of liquid gold. ${ }^{47}$ A Swiss traveler visiting Gallipoli in 1789 noted that low-acidity oil was sold to the English and the Dutch, while common oil went mostly

44. Leonard Archbutt and R. Mountford Deeley, Lubrication and Lubricants: A Treatise on the Theory and Practice of Lubrication, and on the Nature, Properties, and Testing of Lubricants (London, 1922), 56-92; Robert H. Thurston, A Treatise on Friction and Lost Work in Machinery and Millwork (New York, 1903), 122, 282; P. S. Bardell, "Some Aspects of the History of Journal Bearings and Their Lubrication," History of Technology 4 (1979): 1-30, 1-2.

45. On lighting, see, for example, Couture (n. 13 above), 2:178-81.

46. Presta seems to have been alone in admitting that the price of low-acidity oil would effectively prohibit the popolo basso (lower classes) from consuming it; see Presta (n. 13 above), 592. The reformers' argument about the improved taste of low-acidity oil was far from commonsensical. Vitangelo Bisceglia, in his report to the Neapolitan Ministry of the Interior (1813) wrote, "the lower classes find [common oil] palatable, and digest it without problems"; quoted in Vincenzo Ricchioni, "Un pioniere forestiero del risorgimento agrario meridionale," Rivista di storia economica 3 (1938): 211-40, 215. Dalla Bella remarked on the pungent flavor of traditional Portuguese oil, which pleased the vulgo but not the new "delicate tables"; Dalla Bella, Memórias e observações (n. 13 above), xi. The very notion of what olive oil should taste like seems to have changed in the process of modernizing its manufacture. On the social shaping of taste and its use as a mark of social distinction, see Pierre Bourdieu, La distinction: Critique sociale du jugement (Paris, 1979), esp. 204-30.

47. Bartolomeo Ravenna, Memorie istoriche della Città di Gallipoli (Naples, 1836), 105-6. Gallipoli was renowned for its stone-built cisterns, in which oil was stored and left to clear for months, even years. For a description of these cisterns in 1816, see John McCulloch, Dictionary of Commerce (London, 1882), 975. 
toward Marseilles. ${ }^{48}$ A British vice-consul resided there permanently to foster trade with England, which, by the end of the century, had become a leading oil importer. ${ }^{49}$ Professional interpreters found plentiful work translating documents in what had become "a sort of English colony." ${ }^{50}$ From 1782 on the price of oil from Gallipoli was published regularly in London, which gives a sense of the significance of this trade. ${ }^{51}$ In the same period Apulian oil was winning the competition against Levantine and Berber oils in the Trieste market, the port that served Austria and south Germany. In Trieste as elsewhere, low acidity and durability were the most desirable qualities. ${ }^{52}$

With these developments in view it becomes clearer that modernized methods of making olive oil did not evolve in some sort of natural development but were rather the consequence of the new meaning attached to oil production by reformer-entrepreneurs. In order to produce low-acidity oil, olives must be processed earlier in the season, when they are less ripe. ${ }^{53}$ An early harvest meant paying more for labor, as underripe olives were harder to pick. Dalla Bella provided detailed designs for the ladders needed by olive pickers, and suggested employing women and children for this work, as they could be paid half the wage of men and did not ask for wine. ${ }^{54}$

48. Ulysses von Salis-Marschlins, Viaggio nel Regno di Napoli (1790; reprint, Lecce, 1979), 162.

49. M. A. Visceglia, Territorio, feudo e potere locale: Terra d'Otranto tra mediovevo ed età moderna (Naples, 1988), 158. On the British vice-consulate at Gallipoli, see also Nicolette James, Inglesi a Gallipoli: Sofia Stevens (1845-1876)—An English Family in Gallipoli (Lecce, 1993), 109-26. Austria, Denmark, Sweden, and the Netherlands also had representatives there. In 1740 the king of Naples established a consolato del mare (maritime consulate) in the city.

50. On translators, see James, 123-24. The quote is from Biagio Salvemini, "The Arrogance of the Market: The Economy of the Kingdom between the Mediterranean and Europe," in Naples in the Eighteenth Century: The Birth and Death of a Nation State, ed. Girolamo Imbruglia (Cambridge, 2000), 56.

51. C. Massa, Il prezzo e il commercio degli olio d'oliva di Gallipoli e di Bari (Bari, 1897), 37.

52. In 1785 the quantity of Levantine oil landed at Trieste amounted to fifteen percent of that from Apulia. In 1793 a Venetian consul in Trieste reported that Apulian oil could last up to four years without becoming rancid, as compared to one year for Levantine oil. See Ruggiero Romano, "Il Regno di Napoli e la vita commerciale nell'Adriatico," in Napoli: Dal viceregno al regno-Storia economica (Turin, 1976), 138-39.

53. Entire chapters of the reformers' treatises were devoted to the issue of when an olive can be properly said to be ripe. The modern view was that olives should be pressed at the stage when they changed color from green to red; fully black olives were already too ripe to produce low-acidity oil. But the reformers differed among themselves as to this, with the French insisting on harvesting at earlier stages than the Italians. They did agree, however, on the essential point that harvesting traditionally took place far too late in the year, and also that the use of windfalls was deleterious to quality.

54. Dalla Bella, Memórias e observações (n. 13 above), 18-21. On employing children and women in oil manufacture, see also Presta (n. 13 above), 389-90, and Grimaldi, Istruzioni sulla nuova manifattura dell'olio (n. 13 above), 44, who noticed that in 
Pruning methods also changed to facilitate the harvest; trees needed to remain short. ${ }^{55}$

Similarly, reformers decried the practice of leaving olives to ferment after they had been harvested, common all over the Mediterranean, as irrational. Traditional mills included large storage facilities-the zimboni in Calabria, the camini in Apulia, the tulhas in Portugal-where the fruits fer-

APRIL

2004

VOL. 45 mented for weeks or even months before being processed. One reason for this practice was that fermented olives were easier to crush and press, a crucial matter in regions lacking waterpower. The scattered distribution of traditional mills was another; in years of rich harvest the working season could extend well into the spring. Reformers tended to portray the practice of fermentation as an imposition by feudal landlords on peasants, but in fact it was a common belief that fermented olives contained more oil than fresh ones. The strongest opposition to the new harvesting routine came not from feudal masters but from millers, peasants, and tenant farmers. ${ }^{56}$

Many traditional mills, designed for fully ripe olives, proved unequal to the task of crushing fresh ones; hence the reformers' argument that they were technically inferior. Redesigning the millstones around the need to use fresh olives, however-increasing the size of the millstone, tapering it from center to edge, and modifying the dormant stone-precipitated other changes to the structure of the mill. Axles and pivots could not bear the weight of the new stones, and therefore had to be reinforced with metal parts and massive masonry. Also, traditional sources of power could no longer drive the stone effectively. Grimaldi complained about the Calabrian habit of using mules instead of horses, and Bernard suggested using two or four animals to drive a single stone. Whenever possible, waterwheels were the preferred solution, but here too traditional designs had to be discarded. Vertical wheels replaced horizontal ones placed under the basin of the mill, preventing water from cooling the basin and hence increasing the effectiveness of the crushing action. A vertical wheel was more powerful than a horizontal one of equal size and could drive two millstones at once.

At least one other factor lies behind the eighteenth-century quest to produce more powerful oil mills. The critique of traditional technology depended not only on the new requirement that oil mills process fresh olives but also on the different answer reformers gave to this question: What is the proper measure of effectiveness with respect to extracting oil from olives? In feudal-communal systems olives were judged properly milled and pressed when all the edible oil had been extracted plus some oil of inferior quality,

Calabria, Provence, and Languedoc a woman's pay for a working day was one-fourth of a man's.

55. Dalla Bella, Memórias e observações, 24.

56. For Apulia. see Ricchioni (n. 46 above), 230. Similarly, in Portugal small proprietors and lagareiros (oil millers) became "staunch enemies" of the new practice (Dalla Bella, Memórias e observações, 30, 43). 


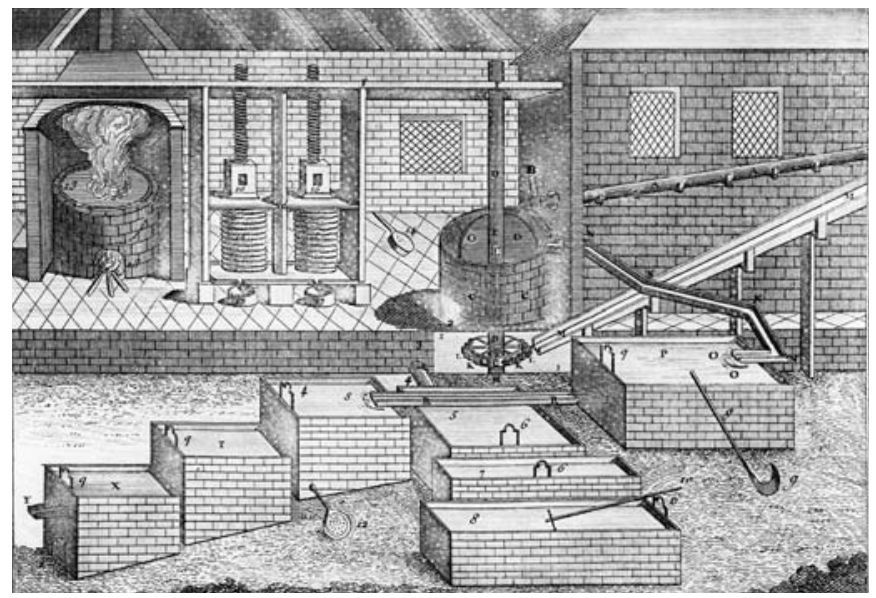

FIG. 2 Interconnected basins for washing the olive remnants. (François Rozier, "Vues économiques sur les moulins et pressoirs a I'huile d'olives, connus en France ou en Italie," Observations sur la physique, sur l'histoire naturelle et sur les arts 8 [1776]: 417-43.)

which required the use of boiling water. The miller kept the remnants of the olive paste, which constituted a relevant part of his earnings. Profit was made out of the marc left in the mill as well as in the press: without it, the traditional mill would have been a loss-making investment. In this context, searching for methods to extract the last drop of oil was a meaningless task. ${ }^{57}$ But the reformers addressed a new kind of proprietor, an individual who held full title to his land and his machines. This figure was slowly emerging, thanks to the practice of enclosure and the decline of common and ecclesiastical lands. Ideally, the proprietor owned the mill and processed his own harvest or fruit bought from peasants. He had no incentive to leave a drop of oil in the olive remnants, or to lose anything at any stage of the manufacturing process-quite the opposite. Modern production methods should leave nothing but dry and compact fibers, which could at most be used as fuel. The newly invented Genoese practice of washing the remnants in a series of interconnected basins (fig. 2) to collect oil particles had been conceived in obedience to the logic of private ownership of machinery. ${ }^{58}$

57. Certain parts of the oil machines, like the basin of the mill, were specifically designed to capture oil, olive paste, and pits during the manufacturing process. On the economic relevance of olive remnants and their possible uses see Françoise Hildesheimer, "L'huile, object de fiscalité en Provence sous l'Ancien Régime," Provence historique 31 (1981): 127-52, and Philippe Magnan de Bornier, Huile et grignons a Nyons, XVIe-XVIIIe siècle (Nyons, 1985).

58. Grimaldi claimed that the procedure of washing olive remnants was invented in Genoa "not more than fifty years ago" and described it carefully; Istruzioni (n. 13 above), 
Similar considerations can explain many of the technical changes in olive presses. As we have seen, at midcentury various technological options were available, with beam presses being the most common. The need to press a paste of fresh olives, and to press the last drop of oil out of it, created a corresponding need to increase the force exerted by the press. The wooden central screw press was a powerful but somewhat fragile option;

APRIL

2004

VOL. 45 the great forces exerted on the paste were also exerted on the press frame itself. The solution was to replace wood with iron, as suggested by Bernard. He also recommended that Provençal entrepreneurs build a series of four to six central screw presses, placed in niches inside a great masonry structure (pressoir à chargement). Similarly, Presta advised Apulian proprietors to carve niches in the rock of the underground trappeti and place Genoese presses there. Masonry and rock provided tremendous structural strength, sufficient to resist the increased force created by the screw.

Meanwhile, the beam press was rapidly abandoned by entrepreneurs. To be sure, longer levers and additional capstans or counterweights did increase the power of beam presses, but in the late eighteenth century this design evolution reached its structural limits. The consequences of a giant lever suddenly freed by the rupture of a capstan or a rope were spectacular and devastating. By the 1780 s the beam press, though it survived in peripheral areas of the Mediterranean world, was just another example of the old way of doing things. ${ }^{59}$

\section{Mechanize and Discipline}

The new mills depended upon a crucial additional development: increasing the workload of laborers. A mechanized mill demanded longer hours and fewer breaks. ${ }^{60}$ The continuous, regular, and synchronized functioning of the new machines required a new and more intense kind of work. Technological innovation could succeed only where the local workforce could be effectively disciplined to its new role. ${ }^{61}$

Disciplining the workforce was in itself a highly desirable goal for the struggling bourgeois elites of southern Europe. Social tensions mounted in the rural world as commercial agriculture and the privatization of common land increasingly disrupted traditional ways of life. This conflict was not peculiar to the Mediterranean regions, but they seem to have experienced

119-30. Dalla Bella presented it as "a new and useful invention," which would increase the "profit of the particulars"; Memórias e observações (n. 13 above), xi, 106-7.

59. Casanova, Paysans et machines (n. 5 above), 246-48.

60. Presta (n. 13 above), 457.

61. On the politics of eighteenth-century disciplinary methods and their analytical nature, see Michel Foucault, Discipline and Punish: The Birth of the Prison (New York, 1979), 135-69. 
it with particular intensity. ${ }^{62}$ Consequently, the late-eighteenth-century agricultural and social landscape of Mediterranean Europe became, as an observer put it, "shapeless." Politically underrepresented and economically squeezed between feudal reaction and an unruly peasantry, the progressive southern bourgeoisie eagerly sought to create new bonds of trust and subordination that could replace the traditional ones. Among their aims in pursuing technological change, then, was the disciplining of the recalcitrant Mediterranean peasant-worker. ${ }^{63}$

Grimaldi often criticized the organization of labor in the traditional trappeti. Bernard found it irrational that the different phases of the productive process were not synchronized, leaving plenty of wasted moments in the laborers' working day: they would be drinking in the nearby village as olives fermented in the containers. The traditional organization of labor reflected the fact that those working in oil mills were not skilled workers but temporarily hired peasants, directed by an experienced chief miller. In the winter months, when other demands of farm work slackened, men and

62. Note, for instance, that in spite of the generalized increase in prices between 1750 and 1800, the wages of day laborers remained basically stable in southern Italy and in Spain. The average daily wage for a Neapolitan worker employed in wine making or oil production was around twenty-five grani; women and boys would not have received more than ten grani. These wages remained unchanged between the 1740s and the early nineteenth century, while the price of grain and oil doubled; the price of oil for lamps, for instance, rose from ten to twenty-three grani per kilogram. Ruggiero Romano, "Prezzi, salari e servizi a Napoli nel secolo XVIII (1734-1806)," in Romano (n. 52 above), 159-264. See also Earl J. Hamilton, War and Prices in Spain, 1651-1800 (Cambridge, Mass., 1947), 204-16, and Pierre Vilar, La Catalogne dans l'Espagne Moderne (Paris, 1962), 2:332-418.

63. On the shapeless landscape, see Emilio Sereni, History of the Italian Agricultural Landscape (Princeton, N.J., 1997). The case of oil manufacture demonstrates that the rationalization of labor and the disciplining of the workforce appeared in these regions long before the advent of the modern factory. For similar considerations relative to North America, see Sharon Salinger, "Artisans, Journeymen and the Transformation of Labor in Late-Eighteenth-Century Philadelphia," William and Mary Quarterly 40 (1983): 62-84; Cynthia Shelton, "The Role of Labor in Early Industrialization: Philadelphia, 1787-1837," Journal of the Early Republic 4 (1984): 365-94; Gail Fowler Mohanty, "Experimentation in Textile Technology, 1788-1790, and Its Impact on Handloom Weaving and Weavers in Rhode Island," Technology and Culture 29 (1988): 1-31. There is a rich literature on the disciplining of the workforce in Britain and America, mostly based on nineteenth-century evidence. See Sidney Pollard, "Factory Discipline in the Industrial Revolution," Economic History Review 16 (1963): 254-71; Keith Thomas, "Work and Leisure," Past and Present 29 (1964): 50-66; E. P. Thompson, “Time, Work-Discipline, and Industrial Capitalism," Past and Present 38 (1967): 56-97; Herbert Gutman, "Work Culture and Society in Industrializing America 1815-1919," in Work, Culture and Society in Industrializing America: Essays in American Working-Class and Social History (New York, 1976), 3-78; Merritt Roe Smith, Harpers Ferry Armory and the New Technology: The Challenge of Change (Ithaca, N.Y., 1977); and Jonathan Prude, The Coming of the Industrial Order: Town and Factory Life in Rural Massachussetts, 1810-1860 (New York, 1983). 
women alike might earn extra money by a few hours a day at the oil mill or press. This kind of labor, either paid or rendered as a corvée, made sense in the context of a self-sufficient feudal or communal economy. But it created problems for an entrepreneur aiming to produce large quantities of lowacidity oil. Relying on the unskilled and discontinuous labor of peasants meant that processing the harvest required a long time, that new machines

APRIL

2004

VOL. 45 could not be used efficiently, and-most important-that traditional figures like the chief miller would preserve their discretion and authority, precluding the implementation of new practices. ${ }^{64}$ Presta advised Apulian landlords bluntly: "Before admitting the workers and their chief, which we call Nochiero [ sic], to your service, call them and explain the way in which you want to be served; [if they do] otherwise, it is convenient to order them what to do with harsh words, or even fire them, as the canon Signor Cantore Piccioli did in the 1787 season, and with great profit indeed, as afterwards he had eighteen loads done every week with just four presses." 65

Workers opposed the new production regime. In 1768, when Grimaldi first sent some Genoese machines to his Calabrian estate, he had to hire approximately twenty well-disciplined Genoese laborers as well, and send them southward with their families. Calabrian peasants seemed unable or unwilling to work in the new mills. Provençal entrepreneurs trying to set up mechanized oil mills in Corsica reported similar difficulties; peasants hired as casual day-laborers seemed unable to make the new machines work properly, and often enough entrepreneurs could not find any available laborers at all. In 1776 a French entrepreneur complained that manpower was scarce in Corsica, leaving oil mills in the hands of a few peasant women. They worked only during the day and that at a slow, irregular pace, in contrast to his Provençal mills, where brigades of men alternated at the machines around the clock. ${ }^{66}$

To have an idea of the kind of work entrepreneurs began to ask for, let us consider briefly the operation of a mechanized oil mill equipped with a battery of central-screw presses (fig. 3). Ideally, the plant included two

64. Consider, for instance, that in traditional oil manufacture the chief miller was responsible for deciding when the olives were ready to be milled and pressed. Typically he would stick his arm in a container filled with fermented fruits to essay their oiliness. In the modern manufacture this decision rested solely with the entrepreneur, who determined when the olives should be harvested and had them immediately processed.

65. Presta (n. 13 above), 458. That resistance to the new practices was strong in southern Apulia is not surprising, as large-scale oil milling had a secular tradition there. The chief miller was a highly respected figure, and was called nocchiero (sea captain) the mill being his subterranean vessel and the workers his crew (ciurma). He was also invested with a particular religious authority, as he was responsible for the spiritual life of workers during the long periods underground. The chief miller guaranteed that working hours were properly interrupted for prayer and meditation, which he guided. See Q. Scozzi, Un paese del sud: Melissano. Storia e tradizioni popolari (Matino, 1981), 122.

66. Casanova, Techniques (n. 5 above), 317-20. 


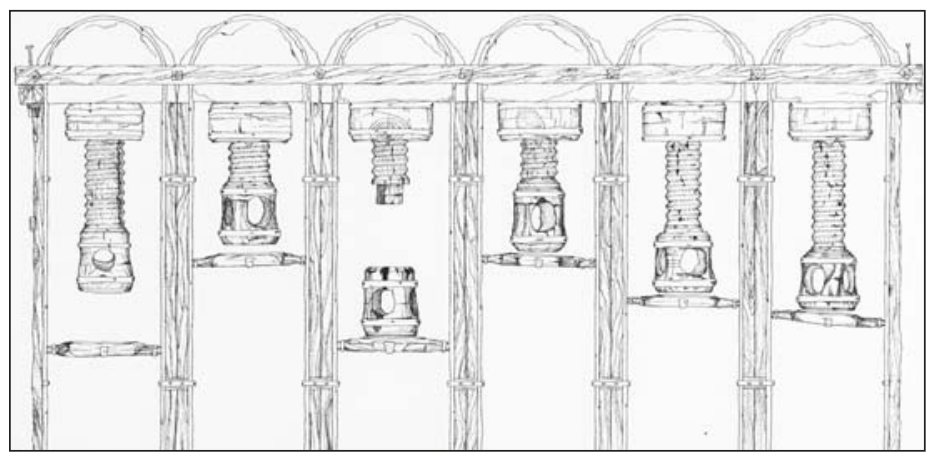

FIG. 3 Battery of single-screw presses from an Apulian mill. (Antonio Monte, L'antica industria dell'olio [Lecce, 2003]. Courtesy of II Grifo Edizioni.)

mills, powered by a single vertical waterwheel, and four or six presses. These machines could process more than one batch of fruit at a time, olive paste moving from one press to the other in an ordered sequence of pressings. To operate the mill twenty-four hours a day demanded a precise choreography. The waterwheel gave continuity to the production process, allowing labor to be distributed in the most effective and economic way. The various steps in the process-first pressing, second pressing, third pressing, and the washing of the olive remnants-followed each other so as to keep each machine constantly in use. Presta calculated that, in a fortyeight-hour period at an optimized Apulian mill, eight full loads of olives would pour into the mill basin, one every six hours. "Nothing is more damaging to a fully equipped oil mill than being at rest." 67

Disciplining the workforce served other purposes besides maximizing output. It was also the concrete epitome of a new social order that the bourgeoisie sought to impose upon the shapeless remains of the feudal world, a microcosm of the new rural community. ${ }^{68}$ The absence of such order astonished Grimaldi and the French entrepreneurs in Calabria and Corsica, and similar concerns underpinned Dalla Bella's call for the creation of new bonds of trust between modern entrepreneurs, chief millers, and peasants.

For the southern bourgeoisie, the failure of technology transfer in vast areas of southern Europe was a troubling symptom of deeper resistance to the enlightened new order. Consider the case of Calabria. The conditions of life of peasants and tenant farmers were rapidly deteriorating due to the

67. Presta, 454-56.

68. Foucault (n. 61 above), 136. On the politics of automated machinery, see the work of Simon Schaffer, particularly his essay "Enlightened Automata," in The Sciences in Enlightened Europe, ed. William Clark, Jan Golinski, Simon Schaffer (Chicago, 1999), $126-65$. 
combined effects of feudal reaction and the commercial speculations of merchants and great landowners. During the years of war with revolutionary France the situation came to a head and, under the banner of Catholic counterrevolution, an unprecedented peasant insurrection took place in 1799, which contemporaries called "the great anarchy." Peasants rose in arms to slaughter the landlords and sack the cities. This time it was not feudal cas-

APRIL

2004

VOL. 45 tles they set on fire but the city houses of the gentiluomini (gentlemen), the new bourgeois proprietors à la Grimaldi-those who supported the philosophical principles of the Enlightenment, the political ideals of the French Revolution, and the rational management of mechanized production. ${ }^{69}$

\section{Technology Transfer}

A mechanized oil mill depended on the proprietor-entrepreneur's control of the entire productive process, which implied among other things the power to strip chief millers of their traditional authority and discretion and to impose new patterns of discipline upon the rest of the workforce. Wherever financial and entrepreneurial elites could realize these conditions, as in the trading centers of the Italian and French Rivieras, new oil technology flourished and further technical innovations (the hydraulic press, the multistone mill) followed.

Where shared machinery, common land, and parceled property remained predominant, however, those necessary conditions did not prevail. In Corsica, Portugal, and Calabria peasant-workers saw new production methods as threats to their very way of life. ${ }^{70}$ And where they could count on other marginal economic activities, they were able to resist. ${ }^{71}$ Thus, in Corsica opening a mechanized mill was a doomed financial enterprise. ${ }^{72}$ By

69. On the complex social dynamics of the 1799 insurrection, see John Davies, "Rivolte popolari e controrivoluzione nel mezzogiorno continentale," Studi storici 39 (1998): 603-22. On the worsening socioeconomic conditions of the southern Italian peasantry, see Pasquale Villani, Mezzogiorno tra riforme e rivoluzione (Bari, 1974); Gaetano Cingari, Giacobini e sanfedisti in Calabria nel 1799 (Reggio Calabria, 1979); and Anna Maria Rao, Pasquale Villani, Napoli 1799-1815: Dalla repubblica alla monarchia amministrativa (Naples, 1995).

70. On workers' opposition to mechanization as a form of resistance to structural social and economic change, see Adrian Randall, "The Philosophy of Luddism: The Case of the West England Woolen Workers, ca. 1790-1809," Technology and Culture 27 (1986): $1-17$.

71. Resistance was structurally possible because of the persistence of feudal-communal activities and resources. It should be noted that even where the feudal communal system was less pervasive, as in Apulia, bracciali and lavoratori (day laborers) were rarely registered as nullatenenti (propertyless). In most cases they would own a house or of part of it, a parcel of land, sometimes a few animals. See Vincenzo Ricchioni, Studi storici di economia dell'agricoltura meridionale (Florence, 1952), 5-70.

72. In 1775 the monks of San Martino di Lota mechanized their mill, only to discover that they could find no laborers. The peasant women in charge of picking olives 


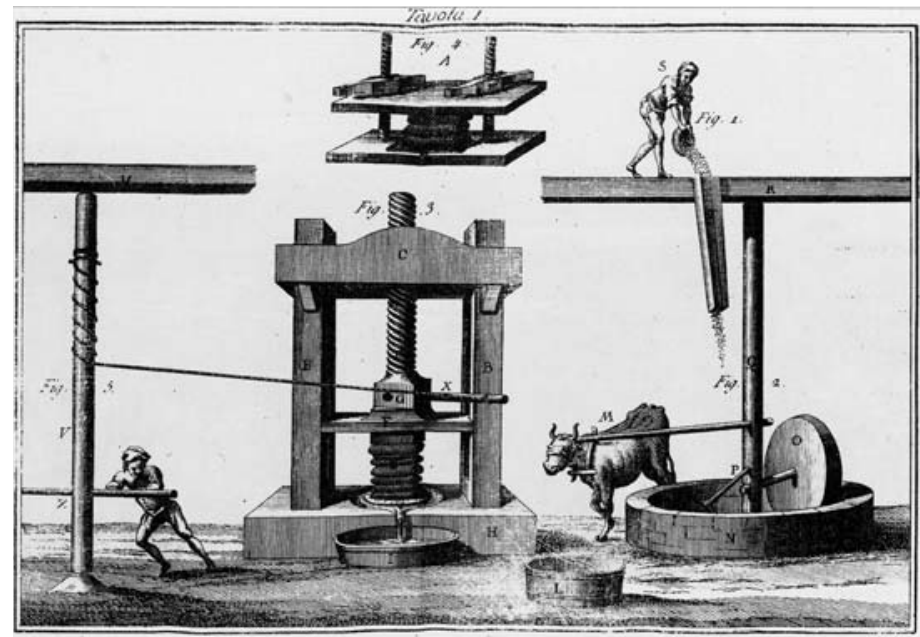

FIG. 4 Genoese-style mill and press. (Domenico Grimaldi, Istruzioni sulla nuova manifattura dell'olio introdotta nel Regno di Napoli [Naples, 1777].)

the end of the century only a few foreign producers who owned plants on the coast and could import their own workforce were using the new oilproduction technology on the island. Similarly, in Portugal reformers failed to overcome the resistance of the traditional chief millers. ${ }^{73}$ By 1790 their day had passed, and Dalla Bella was back in Padua. Mills with a single leverand-screw press, family owned and operated, remained common in Portugal into the twentieth century, adequately meeting the needs of each village's small producers to transform their harvest into common oil destined for local consumption.

Opposition to the new production methods came from other quarters as well. The limited availability of a disciplined workforce was simply one aspect of a broader structural problem. In the feudal-communal context of rural southern Europe, mechanized mills threatened an entire network of interests that sustained and profited from the traditional organization of labor. This was particularly evident in provinces like Calabria, where feudal landlords still had enough power to increase the pressure on the peasantry and protect their traditional rents. ${ }^{74}$ As for the plutocracy of oil merchants

were not willing to increase their workload. In 1777 the monks paid twelve sous for a working day; one woman harvested, on average, one bacino of olives per day; the quantity of oil obtained from one bacino had a market value of around twelve sous. In the short run, then, for the monks the new technology was a loss-making investment. See Casanova, Paysans et machines (n. 5 above), 345-46.

73. Dalla Bella, Memórias e observações (n. 13 above), 127.

74. An example of the ways bourgeois investors and great landowners could profit 
and absentee proprietors, they could speculate safely and profitably in traditional oil production and the trade in common oil with Marseilles. ${ }^{75}$

Grimaldi's reform effort ended in failure. Although by the 1780 s a few Calabrian proprietors were using the new machinery, they were a distinct minority. Grimaldi realized that his entire plan depended on strengthening the medium-sized and small producers, who were too fragmented and

APRIL

2004

VOL. 45 politically weak to press the government for support. In 1785 he tried to set up an association (società economica) of Calabrian oil producers to lobby for lower interest rates, tax reduction, and new contracts with oil merchants. The failure of this project of heterogeneous engineering, which aimed to reshape the social and technical landscape of which the oil mills were part, precipitated Grimaldi's own economic collapse. ${ }^{76}$

Meanwhile, in Apulia, where oil producers were better organized and where feudal-communal land was slowly turning into bourgeois property (often without changing hands), the new technology gained a partial foothold. The presence of a redundant workforce and the rapid erosion of

from traditional oil manufacture was the contratto alla voce. The most common form of payment for olives all over southern Italy, this type of contract provided peasants and tenant farmers with a cash advance for their oil production of the following year, at a price to be fixed at the beginning of the harvest. This system favored speculation on the part of great landowners and oil merchants, while leaving the peasantry to shoulder the burden of increasing taxation and the risk of an unpredictable market. See Chorley (n. 41 above), 83-139, and Paolo Macry, "Ceto mercantile e azienda agricola nel Regno di Napoli: Il contratto alla voce nel XVIII secolo," Quaderni Storici 7 (1972): 851-909. For a detailed study of a Calabrian feudal estate transformed into bourgeois property without altering the overall mode of production, see Raul Merzario, Signori e contadini di Calabria: Corigliano Calabro dal XVI al XIX secolo (Milan, 1975).

75. Furthermore, the bureaucracies and tax systems of the ancien régime tended to penalize the establishment of mechanized mills, mostly by reducing profit margins on olio fino and thereby discouraging investment in new technology. See Giuseppe Palmieri, Osservazioni su vari articoli riguardanti la pubblica economia (Naples, 1790), and Chorley, 140-59.

76. On the weaknesses of the productive bourgeoisie and the failure of the eighteenth-century reform movement in Calabria, see Augusto Placanica, Alle origini dell'egemonia borghese in Calabria: La privatizzazione delle terre ecclesiastiche, 1784-1815 (Salerno-Catanzaro, 1979), 307-428. Grimaldi ended up in jail in 1797, accused of being a liberal freemason conspiring against the monarchy. His son was beheaded in Naples in 1799 as a leader of the republican movement. The parable of the Grimaldis epitomizes the political radicalization of the Neapolitan bourgeoisie during the 1790s, when many became convinced that only revolutionary, antimonarchical action could lead to the modernization of southern society. The story of Domenico Grimaldi can be compared with the successful careers of similar French figures, such as Bernard or Jean-Antoine Chaptal. On Chaptal-a reformer, enlightened entrepreneur, freemason, and supporter of a pragmatic conception of science- - see Gough (n. 17 above), and Jeff Horn and Margaret Jacob, "Jean-Antoine Chaptal and the Cultural Roots of the French Industrialization," Technology and Culture 39 (1998): 671-98. On the notion of heterogeneous engineering, see John Law, "Technology and Heterogeneous Engineering: The Case of Portuguese Expansion," in Bijker, Hughes, and Pinch (n. 3 above), 111-34. 
marginal economic activities undermined peasant-workers' resistance. ${ }^{77}$ The hybrid nature of Apulian mills at the turn of the nineteenth century nicely demonstrates the selective character of technology transfer. Apulian proprietors invested in increasing the dimensions of subterranean mills and the number of machines and animals in use. As their traditional millstones were powerful enough to crush fresh olives efficiently, they concentrated on the mechanization of the presses, reorganizing that part of the labor process and boosting output. Among the technical changes they introduced were the replacement of Calabrian presses with batteries of central screw presses set into the rock and the introduction of a winch to act upon the screw. ${ }^{78}$ In place of a waterwheel, Apulian mill owners increased their use of animal power, alternating oxen to keep the mill in continuous operation. (Oxen were preferred over horses not only because they were stronger but because of their more regular pace. $)^{79}$

Traditional oil technology was shaped by the socioeconomic conditions of the premodern world. Each component (millstone, basin, press) presupposed and sustained a specific process of labor and, more generally, a specific network of social relations. As long as those conditions remained stable, external demand for more and better olive oil was irrelevant. Mechanization emerged in areas like the trading centers of Genoa and Provence, where entrepreneurs reshaped machinery in the context of a global transformation of the agricultural and social landscape. In this situation, traditional machines came to seem inefficient and uneconomic: they did not work any longer. The failure to transfer modern technology to regions where traditional socioeconomic conditions still prevailed (Corsica, Portugal, Calabria), and the partial success of such technology transfer to regions where these

77. Salvemini (n. 50 above), 66.

78. On these and later technical innovations in Apulian oil manufacture, see Ricchioni, "Un pioniere forestiero" (n. 46 above).

79. See, for instance, Giovanni Battista Gagliardo, Catechismo agrario per uso de'curati di campagna e de' fattori delle ville (1793; reprint, Lecce, 1990), 116, 118. On technology transfer, see Bruno Latour's critique of the "model of diffusion" in Science in Action (n. 3 above), 132-36. Other authors have emphasized the role of specific social and economic conditions in explaining problems in technology transfer during the eighteenth century. See, for instance, Edward Allen, "Business Mentality and Technology Transfer in Eighteenth-Century France: The Calandre Anglaise at Nîmes, 1752-1792," History and Technology 8 (1990): 9-23; Dick van Lente, "Innovation in Paper Making: The Netherlands 1750-1850," History and Technology 14 (1998): 201-24; and Karel Davids, "Successful and Failed Transitions: A Comparison of Innovation in Windmill Technology in Britain and the Netherlands in the Early Modern Period," History and Technology 14 (1998): 225-47. See also Svante Lindqvist, Technology on Trial: The Introduction of Steam Power Technology into Sweden, 1715-1736 (Stockholm, 1984). 
conditions were in flux (Apulia), provide further evidence of the intrinsic social dimension of technical change.

Recent works on oil-production machinery have largely reflected a determinist view of technological progress. ${ }^{80}$ This study, in contrast, indicates that highly mechanized oil mills and presses were not self-evident technological goals. They appeared in the Mediterranean landscape as

APRIL

2004

VOL. 45 emblems of a specific project of modernization, one supported by growing portions of the southern elites, and their technical features were the contingent outcome of negotiations over such issues as the nature of olive oil, trade, control of the production process, the conditions of ownership of land and machinery, work discipline and labor organization, and the forging of new power relations in southern European society.

80. See n. 5 above. For an example of straightforward technological determinism in Italian historiography, see Franco Mastrolla, "Olivicultura e tecniche estrattive in Terra d'Otranto nei secoli XVIII e XIX attraverso gli studi del Presta e del Moschettini," Annali del dipartimento di scienze storiche e sociali, Università degli Studi di Lecce 2 (1983): 245-58. 